Review

\title{
Influences of Plant Traits on Immune Responses of Specialist and Generalist Herbivores
}

\author{
Evan Lampert \\ Department of Biological Sciences, Gainesville State College, Oakwood, GA 30566, USA; \\ E-Mail: elampert@gsc.edu; Tel.: +1-678-717-3804; Fax: +1-678-717-3770
}

Received: 30 April 2012; in revised form: 25 May 2012 / Accepted: 13 June 2012 /

Published: 19 June 2012

\begin{abstract}
Specialist and generalist insect herbivore species often differ in how they respond to host plant traits, particularly defensive traits, and these responses can include weakened or strengthened immune responses to pathogens and parasites. Accurate methods to measure immune response in the presence and absence of pathogens and parasites are necessary to determine whether susceptibility to these natural enemies is reduced or increased by host plant traits. Plant chemical traits are particularly important in that host plant metabolites may function as antioxidants beneficial to the immune response, or interfere with the immune response of both specialist and generalist herbivores. Specialist herbivores that are adapted to process and sometimes accumulate specific plant compounds may experience high metabolic demands that may decrease immune response, whereas the metabolic demands of generalist species differ due to more broad-substrate enzyme systems. However, the direct deleterious effects of plant compounds on generalist herbivores may weaken their immune responses. Further research in this area is important given that the ecological relevance of plant traits to herbivore immune responses is equally important in natural systems and agroecosystems, due to potential incompatibility of some host plant species and cultivars with biological control agents of herbivorous pests.
\end{abstract}

Keywords: antioxidant; ecological immunity; encapsulation; Lepidoptera; secondary compounds; sequestration; tradeoff 


\section{Introduction}

Interest in questions related to ecological immunology arose relatively recently as a synthesis between evolutionary ecology and immunology, and has grown dramatically in the last decade [1]. Ecological immunology refers to the study of how a combination of biotic and abiotic factors influences the immune responses of organisms [1,2]. Much research in ecological immunity has focused on tradeoffs between these biotic and abiotic factors and immune response [3]. Especially well-studied ecological factors that can compete with immune response include limited resource availability (poor nutritional status, sensu [4]) and competing physiological needs (such as reproductive status, sensu [5]) of the target organism.

Rolff and Siva-Jothy [6] discussed the need for more research in ecological immunity of invertebrates, in large part because evolutionary ecology of the immune response is easiest researched in organisms with simpler immune responses. Insects, like other invertebrates, rely primarily on innate immune responses to survive attacks by pathogens and endoparasites [7,8]. Insect models such as Drosophila melanogaster and Manduca sexta have been used extensively to understand innate immune responses [9-12]. Insects are also important models in ecological research due to their sheer abundance in terrestrial ecosystems.

Here I call for increased synthetic research uniting two major fields of insect evolutionary ecology, the relatively new and rapidly growing field of ecological immunology, and the long-established field of plant-herbivore interactions. Much research attention has been and continues to be focused on the effects of host plant traits on herbivore-parasite interactions; however, relatively few authors have directly measured immune response itself, and published research so far has been restricted to larval Lepidoptera. A mechanistic approach to studying multitrophic interactions that incorporates measurement of the immune response is important. Interactions between plants and herbivorous insects are among the dominant ecological interactions in many terrestrial ecosystems. These lower trophic level interactions have dramatic effects on higher trophic interactions, in particular herbivore immune response to pathogen infection and endoparasitism. Host responses to pathogens and endoparasites influence population dynamics, colonization, and persistence, thus playing important roles in the structure and function of communities [13-16]. Basic research in plant-herbivore-parasite interactions is also important for applications in agroecosystems, in which herbivorous insects along with other invertebrates are major causes of economic damage and parasites function as biological control agents [17-19].

\section{Evolution of Herbivore Diet Breadth and the Potential Role of Parasites and Pathogens}

At least $90 \%$ of known herbivorous insect species are restricted to feeding on plant species belonging to three or fewer families [20]. Such species are often referred to as specialists, and specialist insect species may be further referred to as monophagous (feed successfully on a single host species or genus) or oligophagous (feed successfully on a "few" host species, genera, or families). Conversely, herbivore species that can feed successfully on plants from several families are referred to as generalists, or polyphagous. Referring to an insect species as a specialist or generalist can be problematic for multiple seasons, including the lack of complete information regarding host plant 
range of many species and errant host records for presumed specialist species. For example, populations of Manduca sexta (Lepidoptera: Sphingidae), a presumed Solanaceae specialist, have been recorded on Proboscidea (Martyniacaeae), belonging to a plant family that is classified in a different order [21]. Moreover, individuals of a species considered to be polyphagous may specialize on only a single host plant species [22-24]. Although flexibility exists in defining a species as a specialist or generalist, herbivore species that develop on a narrow range of host plant species with similar chemical and nutritional traits are primarily considered specialists, while generalist species have the ability to consume plants expressing a broad range chemical and nutritional traits [20,25].

The evolution of narrowed diet breadth in insect herbivores ranks among the most studied, and most varied, areas of research in evolutionary ecology [26], due in part to research supporting two competing groups of models derived from opposing viewpoints of the relative strength of selection provided by lower [27] and higher [28] trophic levels. "Bottom-up" models posit that coevolution between the nutritional and defensive traits of plants and the behavioral and physiological traits of herbivores may potentially explain narrowed feeding ranges [27,29,30]. In particular, adaptation to specific plant secondary metabolites by a herbivore population or species can reduce competition among herbivores and increase metabolic efficiencies. Specialist herbivores that have adapted to process or avoid specific metabolites outperform generalist herbivores when consuming diets containing the metabolites [20,31-37], at the expense of being restricted to those diets. Moreover, numerous comparative studies examining both generalist and specialist herbivore-natural enemy complexes have found that generalist complexes respond more poorly to plant metabolites than specialist complexes [38-41], generally due to the herbivore's reduced nutritional quality to the natural enemy.

"Top-down" models hypothesize that the mortality caused by natural enemies is an important selective force of all insects, and is potentially a driving selective force in herbivore host range as well $[28,42,43]$. In particular, specialist natural enemies such as many pathogens and endoparasitic arthropods (endoparasitoids) may exert considerable pressure on herbivore host range as the primary sources of herbivore mortality in many ecosystems [44]. Evidence that pathogens and endoparasitoids may contribute to both narrowed and broadened host ranges comes from examination of the effect of parasitism risk and status on herbivore host selection behavior and how that behavior affects subsequent interactions with endoparasites [45,46]. The parasite-altered behavior of generalist herbivores has provided many insights in this regard. For instance, Grammia incorrupta (Lepidoptera: Arctiidae) larvae parasitized by tachinid endoparasitoids in early instars were less attracted to feeding on diets containing toxic plant compounds (hypothesized to reduce immune response) and more attracted to plant species containing antioxidants (hypothesized to improve immune response, see below) [47]. However, G. incorrupta larvae parasitized in later instars increased consumption of the same toxic compounds, suggesting a self-medication behavior [47,48]. From an evolutionary and ecological standpoint, it is likely that host selection in natural systems by individual herbivores of several species can be influenced by parasitism risk and status, with individuals making decisions that reduce parasite success more likely to survive and reproduce $[43,49,50]$ even if forced to develop on low-quality host plants [51]. Over time, these decisions may have increased the chances of insect species becoming specialist herbivores, feeding primarily on plant species that provide metabolites that directly or indirectly reduce susceptibility to natural enemies. 


\section{Assays for Measuring Immune Responses in Herbivorous Insects}

The insect immune response fits into two categories: (i) the humoral response, in which circulating antimicrobial peptides, RNAs, and lyzosomes are upregulated in response to the presence of viral, bacterial, and fungal pathogens [7,52,53]; and (ii) the cellular response, in which circulating hemocytes phagocytose microbial pathogens and envelop larger foreign bodies $[8,54,55]$. Both responses rely on recognition of an invasive body, and the upregulation of genes involved in immune response.

Several assays can be used to measure humoral and cellular responses; careful and accurate measurement of the innate immune response of generalist and specialist insect herbivores is necessary to draw conclusions related to the effects of plant traits. The appropriate assay used to measure an herbivore's immune response depends on several factors, including the herbivore's morphology, physiology, and developmental stage, and the objectives of the research (i.e., examining susceptibility to endoparasitoids or viruses) The use of multiple different assays can demonstrate tradeoffs between different immune system traits responding to the same challenges, or how immune response traits appropriate to different challenges (e.g., a virus or an endoparasitic arthropod) each may vary due to individual plant traits (sensu [56]).

The effect of plant traits on the immune response of herbivores has been tested primarily using three techniques (with few published exceptions [56,57], only the cellular responses of larval Lepidoptera to endoparasitoids have been tested for these purposes), which are described in Sections 3.1-3.2. While each can be used to measure immune response in both parasitized or unparasitized herbivores, the innate immune response is best tested in parasite-free animals. These techniques have proven to be very practical in studies that have shown correlations between these assays and field parasitism [58] and susceptibility to endoparasites [59]. Nonetheless, laboratory assays of immune response should be carefully interpreted as some studies have reported no correlation between immune assays and field parasitism success $[60,61]$.

\subsection{The Prophenol Oxidase Pathway}

One of the primary pathways in the both the humoral and cellular immune responses is the prophenol-oxidase (PPO) cascade, which results in the oxidation of tyrosine derivatives such as L-DOPA by activated phenol oxidase (PO), and deposition of melanin on the invasive body $[12,62,63]$. The product of the PPO pathway is measured using absorbance in spectrophotometric assays. Hemolymph samples are incubated in buffer solution with serine proteases such as chymotrypsin [64] added to activate PO. A substrate such as L-DOPA is added to allow the enzymatic oxidation to proceed. The change in absorbance over time in the product is measured using spectrophotometry, and correlated with enzyme activity and thus immune response. The measurement of PO activity is strongly associated with susceptibility to certain pathogens and arthropod endoparasitoids [59,65], but is not correlated with susceptibility to other pathogens (such as viruses [57,66]). Measurement of PO activity is less parasite-specific than the two following assays, both of which simulate endoparasitoids. Assays of PO activity assays require only hemolymph samples rather than destroying the insect to find and remove an implant, which provides four advantages to the remaining implant-based techniques: (1) it is more easily performed in natural systems; (2) there is no 
wait for melanization in the hemocoel, and the sample isn't lost if the insect dies during implantation; (3) one insect can be tested multiple times; (4) a parasitized insect can be tested, then kept alive to allow continued parasite development or emergence.

\subsection{Simulation of Solitary Endoparasitoids}

Solitary endoparasitoids are those in which single offspring emerge successfully from a single host; the successful endoparasitoid offspring may emerge alone because it was the sole invader, or it killed competing larvae inside its host [67,68]. Solitary development is considered the ancestral trait in Hymenopteran endoparasitoids [69], which more commonly exhibit this lifestyle compared to other endoparasitoid orders [68].

Solitary endoparasitoids have been simulated using $2.0 \times 0.20 \mathrm{~mm}$ nylon microfilament implants placed in the hemocoel of the target insects for a pre-determined amount of time (as short as $1 \mathrm{hr}[65,70])$ during which encapsulation and melanization of the implant both occur. Implants are photographed upon removal, and the size of the hemocyte capsule and the color of the melanized implant can both be measured using various imaging software packages such as ImageJ, Image Pro, and Adobe Photoshop. Color is scored using grey color caused by melanization, and a non-implanted control microfilament is used as a comparison for both color and size after encapsulation and melanization.

\subsection{Simulation of Gregarious Endoparasitoids}

Gregarious development, the successful development of at least two endoparasitoid larvae in a single host, is considered a derived character in the Hymenoptera [69] and a general feature of endoparasitoids belonging to other orders such as Coleoptera and Diptera [68]. Gregarious development may be the result of superparasitism (several adult female parasitoids insert eggs into the same individual host, or a single female repeatedly oviposits into the same individual host) or large clutches of eggs inserted during one oviposition event.

Gregarious endoparasitoids have been simulated by injecting a group of glass beads in physiological saline into the hemocoel. Sephadex chromatography beads, such as A-25 beads with a diameter of $40-120 \mu \mathrm{m}$, are commonly used [71-73]. A fixed volume of $10-15 \mu \mathrm{L}$ saline + beads is injected into the hemocoel, and beads are individually recovered from caterpillars dissected after a pre-determined amount of time has passed for melanization to occur. As with filament implants, the size and color of the capsule can both be measured using images of each bead. Beads are often dyed red to facilitate retrieval; in this case the red color of melanized and control beads is compared to calculate melanization (Figure 1).

\section{Host Plant Traits and the Herbivore Immune Response}

Plants provide the major nutritional compounds required for herbivorous insect growth and maintenance, such as carbohydrates, lipids and amino acids. In addition, plants produce a variety of secondary metabolites not used in primary metabolism that have important ecological effects on both herbivores and their interactions with each other and occupants of higher trophic levels [20,27,74]. 
Plant quality traits include a combination of major nutritional compounds and secondary metabolites, as well as morphological and architectural traits.

Figure 1. Representative beads dissected from the generalist Spodoptera eridania (Lepidoptera: Noctuidae) larvae reared upon (left) Taraxacum officinale, a high-quality diet, and (right) Plantago lanceolata, a low-quality diet [75]. Host plants were determined to be high or low quality based on observations of growth rate, and defensive chemistry of the two plant species. Photos by E.C. Lampert.

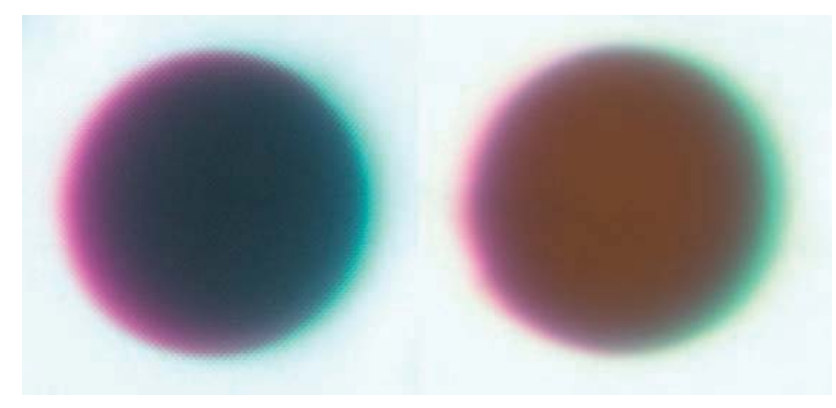

The identity and quantities of plant secondary compounds consumed by herbivores have been shown repeatedly to influence their interactions with both predatory and parasitic/pathogenic natural enemies (reviewed in [76-78]). These bottom-up tritrophic interactions can be broadly defined as direct, in which exposure to a plant compound within the herbivore has a positive or negative effect on the natural enemy, or indirect, in which the herbivore's size or quality has been influenced by the compounds. Direct deleterious effects of plant compound sequestration and metabolism on parasitoids and pathogens have been demonstrated repeatedly and reviewed by other authors [77]. Here I focus on indirect effects of plant primary and secondary compounds on potential parasites and pathogens as mediated by enhanced and compromised innate immune responses of herbivores. Species discussed in examples in Sections 4.1-4 are all larval Lepidoptera, as appropriate published research to date has been exclusive to this taxon.

\subsection{Plant Identity, Plant Quality and Immune Responses of Generalist and Specialist Herbivores}

Generalist and specialist herbivores both encounter variation in host plant quality traits while foraging. This variation may be the result of the variation provided by multiple plant species, and variation within a plant species, population, or individual. Generalist herbivores exhibit two foraging strategies; individuals of herbivore species considered generalists at the individual level may sample and consume many plant species [24,79], while those that are generalists at the population level may remain on a single plant individual or members of a single plant species [80,81]. Individual specialist herbivores generally follow a similar strategy to the latter, remaining on a single plant species or even a single plant individual throughout their lifespan [20].

Foraging on several plants species can provide herbivores with wide qualitative variation in nutritional and defensive compounds. A mixed diet throughout an individual's lifespan provides many benefits from a multitrophic perspective, such as improving fecundity, and growth rate [82,83], and pharmacophagy (see [48], Section 2). However, a mixed diet may not necessary improve immune response. For instance, generalist Parasemia plantaginis (Lepidoptera: Arctiidae) larvae fed a 
3-species mixed diet had a weaker immune response than those feeding on single plant species [84]. In this case, the mixed diets may have diluted the intake of compounds beneficial to growth and the immune response.

Plant defensive and nutritive traits can vary dramatically at the population level and the individual plant level (through ontogenetic changes and herbivore-induced changes as well as variation among tissues). This variability exposes herbivores consuming a single plant species to a wide variety of biotic conditions, even under similar environmental conditions. Epirrita autumnata (Lepidoptera: Geometridae) a generalist that feeds on several deciduous tree species [85], with cyclic population outbreaks, has provided several insights in this regard. Over several seasons and outbreaks, E. autumnata immune response has been found to be higher on high-quality trees [61], low-quality trees $[65,86]$, induced trees [70], and alternative tree species [87]. The generally enhanced immune response on low-quality diets in this species (with the exception of [61]) may reflect a tradeoff between growth and immune response, as larvae stressed by diet quality may allocate higher proportions of resources to survival.

Plant quality is often correlated with immune responses of both specialists and generalists. A survey of published research examining 10 generalist and specialist Lepidoptera species found that cellular immune response (measured as PO activity, implants, and bead injections (Table 1)) was higher in 5 species (counting E. autumnata [61]) when reared on or collected from a "high quality" or preferred plant, as determined by measuring other fitness correlates such as growth rate and larval or pupal mass. Only the generalist E. autumnata showed a reduced response and the others showed no change in immune response when reared on high-quality plants compared to low-quality plants (Table 1). The general association between high-quality diets and strong immune responses in this limited sample broadly fits a pattern showing that invertebrates experiencing favorable conditions also show strengthened immune responses [88,89]. Plant identity was associated with significantly strengthened or weakened immune responses in all of the specialist species and all of the generalist species except Grammia incorrupta (which showed a consistent immune response regardless of host plant species) (Table 1), supporting generally the hypothesis that lower trophic levels influence higher trophic interactions.

Table 1. Effects of host plant species and host plant quality on immune response of 9 specialist and generalist Lepidopteran herbivores.

\begin{tabular}{|c|c|c|c|c|c|}
\hline Herbivore Species & Diet Breadth & Plants Used & Measurement & Immune Response & Citation \\
\hline \multirow[t]{3}{*}{$\begin{array}{c}\text { Epirrita } \\
\text { autumnata }\end{array}$} & generalist & $\begin{array}{l}\text { Betula pubescens and } \\
\text { alternate tree hosts }\end{array}$ & implants & $\begin{array}{l}\text { varied among cultivars and } \\
\text { species, higher } \\
\text { in induced and } \\
\text { low-quality trees } \\
\end{array}$ & {$[65,70,87]$} \\
\hline & & & & $\begin{array}{c}\text { higher in } \\
\text { high-quality trees }\end{array}$ & [61] \\
\hline & & $\begin{array}{l}\text { high and low quality } \\
\text { Betula pubescens }\end{array}$ & PO activity & no effect & {$[65]$} \\
\hline $\begin{array}{l}\text { Eupoecilia } \\
\text { ambiguella }\end{array}$ & specialist & Vitis vinifera cultivars & PPO activity & varied among cultivars & {$[56]$} \\
\hline
\end{tabular}


Table 1. Cont.

\begin{tabular}{|c|c|c|c|c|c|}
\hline Herbivore Species & Diet Breadth & Plants Used & Measurement & Immune Response & Citation \\
\hline $\begin{array}{l}\text { Grammia } \\
\text { incorrupta }\end{array}$ & generalist & three forb species & beads & $\begin{array}{l}\text { no difference } \\
\text { among plants }\end{array}$ & [73] \\
\hline $\begin{array}{c}\text { Junonia } \\
\text { coenia }\end{array}$ & specialist & $\begin{array}{l}\text { Plantago lanceolata, } \\
\text { P. major }\end{array}$ & beads & $\begin{array}{l}\text { higher when fed } \\
\text { P. major }\end{array}$ & [90] \\
\hline $\begin{array}{l}\text { Manduca } \\
\text { sexta }\end{array}$ & specialist & $\begin{array}{c}\text { Nicotiana tabacum and } \\
\text { Proboscidea } \\
\text { lonisianica }\end{array}$ & beads & $\begin{array}{l}\text { higher on } \\
N \text {. tabacum }\end{array}$ & [91] \\
\hline $\begin{array}{l}\text { Orgyia } \\
\text { antiqua }\end{array}$ & specialist & two Salix spp. & implants & no effect & [92] \\
\hline $\begin{array}{l}\text { Parasemia } \\
\text { plantaginis }\end{array}$ & generalist & four forb species & implants & $\begin{array}{l}\text { higher on Lactuga } \\
\text { and Rumex }\end{array}$ & [84] \\
\hline Pieris rapae & specialist & $\begin{array}{l}\text { wild and cultivated } \\
\text { Brassica }\end{array}$ & egg encapsulation & $\begin{array}{l}\text { reduced on induced plants, } \\
\text { highest on Brussels sprouts }\end{array}$ & [93] \\
\hline $\begin{array}{c}\text { Plutella } \\
\text { xylostella }\end{array}$ & specialist & four Brassica cultivars & PO activity & $\begin{array}{l}\text { varied among cultivars, no } \\
\text { relation to quality }\end{array}$ & [94] \\
\hline Trichoplusia ni & generalist & $\begin{array}{c}\text { Brassica oleracea and } \\
\text { Cucumis sativa }\end{array}$ & $\begin{array}{l}\text { PO activity, } \\
\text { hemocyte \# }\end{array}$ & $\begin{array}{c}\text { no effect on PO, higher } \\
\text { hemocytes on B. oleracea }\end{array}$ & [66] \\
\hline
\end{tabular}

\subsection{Plant Nutritional Resources and Antioxidants May Enhance Melanization}

Melanization and encapsulation responses of insects presented with foreign implants have been clearly linked to nutritional status. Starvation has been shown to reduce immune responses $[4,57,94]$, as have low-quality diets that induce poor nutritional efficiencies [73,90,95]. Nutritional macromolecules such as amino acids and proteins provided by plants have important effects on herbivore growth and fitness [96], the role of these molecules in enhancing immune responses has received recent attention as well. The quality and quantity of nutritional resources are both important to immune response; for example, high-quality protein may contribute more to the nitrogen pool that the immune response draws from [95].

The PPO cascade that leads to melanization of foreign objects generates abundant reactive oxygen species that can harm the insect [97-99]. Plant-provided antioxidant compounds such as flavonoids, phenolics, and carotenoids remove these reactive oxygen species and have been shown to enhance immune response [100,101]. The effects of antioxidants on the immune response are of particular interest in evolution of host plant choices of generalist species. For instance, encapsulation ability of the generalist arctiid Parasemia plantaginis fed 3 plant species and an artificial diet was highest when fed plant species contributing compounds high in antioxidant activity such as flavonoids and carotenoids [84]. Moreover, encapsulation responses of other generalist caterpillars reared on Taraxacum officinale and Malva parviflora have been shown to be consistently high [73,75], and both plants are known to produce high levels of antioxidant flavonoids [102,103]. As mentioned above (Section 2), Grammia incorrupta larvae parasitized by dipteran endoparasitoids preferentially select flavonoid-rich M. parviflora over plants providing defensive compounds that can be sequestered [73]. 
Further evidence that plant antioxidants and other secondary compounds increase encapsulation and melanization comes from comparisons between herbivores reared on whole plants and artificial diets; recipes for the latter include primary nutrients, preservatives, and antibiotics but lack plant secondary compounds unless added separately. Both generalist and specialist herbivores benefit from diets enriched with these compounds. Weakened immune responses have been found in both generalist [73,84] and specialist herbivores [90] reared on artificial diets compared to plant diets. Thus, although a possible link between antioxidants and a strengthened immune response has been observed in a limited number of studies, further research is needed to determine the extent to which parasitism status induces a preference for plants high in antioxidants compared to other compounds.

\subsection{Plant Defensive Chemistry and Herbivore Immune Response}

One of the key differences between specialist and generalist herbivores is response to consuming plant defensive compounds [20]. Many specialist herbivores possess enzyme systems highly specialized to metabolize specific substrates. Substrate-specialized enzyme systems may be ineffective at metabolizing compounds structurally dissimilar to the substrate, causing specialists to respond poorly to novel compounds. Generalist herbivores are able to consume many more plant species and their various associated compounds due to broad-substrate enzyme systems [104,105]. Although substrate-specific enzymes are present in generalist herbivores [106], the prevalence in generalists of broad-substrate enzyme systems often makes them more susceptible to deleterious effects of defensive compounds compared to specialists. The reduced performance of specialists consuming novel compounds, and both specialists and generalists consuming large amounts of defensive compounds can include a weakened immune response.

Metabolizing large amounts of consumed plant compounds may be energetically expensive regardless of enzyme system specificity. These costs may divert needed resources away from immune responses. Increased dietary levels of glucosinolates and iridoid glycosides, two plant compounds associated with reduced digestive efficiencies [73,90,107,108] have been shown to have detrimental effects on the immune response of several generalist and specialist Lepidopteran species (Table 2).

Performance measures such as growth rate, size, nutritional indices were also reduced along with immune response as higher doses of these compounds were consumed [75,90,93]. One specialist, Ceratomia undulosa (Lepidoptera: Sphingidae), was fed leaf discs supplemented with a novel compound (catalpol), with toxic effects of this compounds potentially contributing to its weakened immune response at a low dose [75]. A negative correlation between hydrolyzable tannins in host tree leaves and Epirrita autumnata immune response (with a positive correlation between hydrolyzable tannins and growth) was the only exception found to the general pattern of immune response mirroring other performance measures as a function of host plant chemistry [86], likely due to a strong tradeoff in this species between investments in growth versus immune response.

Physiological and behavioral differences between generalists and specialists may explain instances in which the immune response of the former is not influenced by secondary compound consumption. Immune response of the grazing generalist Grammia incorrupta is not affected when consuming high doses of either iridoid glycosides or pyrrolizidine alkaloids (references in Table 2). Unlike many other generalists and most specialists, individual $G$. incorrupta sample several plants providing potentially 
several distinct chemical classes. The consistently high immune responses of G. incorrupta measured regardless of diet may be explained by broad-substrate enzyme systems that do not compete for resources with the immune response, unique enzyme systems in the immune response itself, or some other unique physiological trait of this species. More research is needed to determine if other generalists with a similar feeding style (e.g., other Arctiidae and several groups of Orthoptera) are similarly able to maintain a high immune response regardless of type and dose of dietary defensive compounds.

Table 2. Effects of plant secondary metabolites on immune response of specialist and generalist Lepidopteran herbivores.

\begin{tabular}{|c|c|c|c|c|}
\hline Herbivore species & Diet Breadth & Plant Compound & Immune Response & Citation \\
\hline $\begin{array}{l}\text { Parasemia } \\
\text { plantaginis }\end{array}$ & generalist & antioxidants & $\begin{array}{l}\text { strengthened with } \\
\text { increasing amounts } \\
\text { consumed }\end{array}$ & {$[84]$} \\
\hline \multirow{2}{*}{$\begin{array}{l}\text { Epirrita } \\
\text { autumnata }\end{array}$} & generalist & flavonoids & no effect & [86] \\
\hline & & hydrolyzable tannins & $\begin{array}{c}\text { weakened with increasing } \\
\text { amounts consumed }\end{array}$ & [86] \\
\hline Pieris rapae & specialist & glucosinolates & weakened in induced plants & [93] \\
\hline Junonia coenia & specialist & iridoid glycosides & $\begin{array}{c}\text { negatively correlated with } \\
\text { amount consumed and } \\
\text { sequestered }\end{array}$ & {$[90]$} \\
\hline Melitaea cinxia & specialist & iridoid glycosides & $\begin{array}{l}\text { positively correlated with } \\
\text { amount consumed }\end{array}$ & [109] \\
\hline $\begin{array}{l}\text { Grammia } \\
\text { incorrupta }\end{array}$ & generalist & iridoid glycosides & no effect & [73] \\
\hline $\begin{array}{l}\text { Ceratomia } \\
\text { catalpae }\end{array}$ & specialist & iridoid glycosides & $\begin{array}{l}\text { negatively correlated with } \\
\text { amount sequestered }\end{array}$ & {$[75]$} \\
\hline $\begin{array}{l}\text { Ceratomia } \\
\text { undulosa }\end{array}$ & specialist & iridoid glycosides & $\begin{array}{l}\text { weakened with increasing } \\
\text { amount consumed }\end{array}$ & {$[75]$} \\
\hline $\begin{array}{l}\text { Grammia } \\
\text { incorrupta }\end{array}$ & generalist & pyrrolizidine alkaloids & no effect & {$[47]$} \\
\hline
\end{tabular}

\subsection{Tradeoffs between Defensive Compound Sequestration and Herbivore Immune Response}

Sequestration of plant secondary compounds, storing them in the hemocoel or other tissues in concentrations higher than the plant producing them, is common among both specialist and generalist herbivores [110,111], although specialist herbivores may sequester higher concentrations of plant compounds compared to generalists [43,111,112]. Sequestration is noted as an effective form of chemical defense against predators, pathogens, and endoparasitoids [111]. However, several cases have been found in which endoparasitoids are as or more successful in hosts sequestering higher levels of plant compounds compared to those in hosts that do not sequester [113-115]. Smilanich et al. [90] have proposed the "vulnerable host hypothesis" to explain this phenomenon, positing that defensive compound sequestration and the immune response can be antagonistic metabolic processes. 
Competing metabolic demands between sequestration and immune responses that show a tradeoff between the two processes are central to supporting the "vulnerable host hypothesis." Plant compounds sequestered in the hemocoel are often modified by enzymes before storage (e.g., [116]) and cross gut epithelia with the help of transport proteins to reach their destination, both energetically expensive processes that may compete with immune response as well as a variety of other life functions [117-119]. Evidence that sequestration is energetically expensive was provided by path analysis models revealing that the specialist Junonia coenia (Lepidoptera: Nymphalidae) experienced reduced respiration rates as the amount of the iridoid glycoside catalpol sequestered increased [90]. Increasing amounts and concentrations of catalpol sequestered by $J$. coenia has been associated repeatedly with reduced nutritional efficiency and weakened immune response ([75,90,108], Figure 2,), while simultaneously reducing susceptibility to invertebrate predators [120,121]. The use of catalpol sequestration to test the "vulnerable host hypothesis" has been extended to two other herbivores as well; melanization response was negatively associated with sequestration in the specialist Ceratomia catalpae (Lepidoptera: Sphingidae), but not the generalist Spilosoma congrua (Lepidoptera: Arctiidae) (Figure 2). Specialized $C$. catalpae enzyme and carrier systems may require more energy for accumulating high catalpol concentrations (5x the concentrations accumulated by $S$. congrua), while $S$. congrua may lack these energy-intensive transport systems.

\section{Future Directions}

The integration of ecological immunity and bottom-up effects of plant traits on herbivore-natural enemy interactions is relatively young (most research in this area has been published within the last decade) and open to expansion in several directions. Publications to date that directly measure herbivore immune response in regards to plant traits have focused almost exclusively on larval Lepidoptera, with floral traits and honeybee immune response as one exception [122]. Although larval Lepidoptera are particularly well-studied from both the perspectives of diet breadth evolution and immune responses, broader themes can be revealed by investigating other insect orders with particularly well-studied herbivorous species of economic and ecological importance (e.g., the Hymenoptera, Diptera, Hemiptera, Orthoptera, and Coleoptera). Drosophila melanogaster (Diptera: Drosophilidae) has been studied extensively as a model testing effects of starvation and diet resources on immune response, and yeast strain (presumably nutritional quality) has been shown to affect immune response [123].

Field tests in natural populations, particularly well-resolved natural systems (e.g., Depressaria pastinacella and Utetheisa ornatrix and their respective host plants, reviewed in [124,125], will further reveal the selective forces of plant traits on herbivore immune responses. With the exception of the Betula pubescens-E. autumnata system and a neotropical Lepidoptera assemblage [58], research on the effects of plant species and genotype on innate immune response itself have been primarily confined to laboratory settings. One reason for the lack of field studies is that the study of natural populations prevents experimental control of plant traits, requiring correlative relationships between plant traits and immune responses. Nonetheless, the study of natural populations can allow the assessment of correlation between the measured immune response and population-level parasitism success; a strong relationship has been found in one study [58] whereas no relationship has been found in another [61]. 
A second reason is that natural systems are not convenient for placing or recovering implants or beads. Hemolymph samples for PPO measurement are ideal in these settings.

Figure 2. Tradeoffs between defensive chemistry and immune response of three Lepidopteran herbivores support the "vulnerable host hypothesis" [90]. Catalpol sequestration is negatively correlated with melanization ability of the specialists Junonia coenia (Nymphalidae) and Ceratomia catalpae (Sphingidae), but not the generalist Spilosoma congrua (Arctiidae).

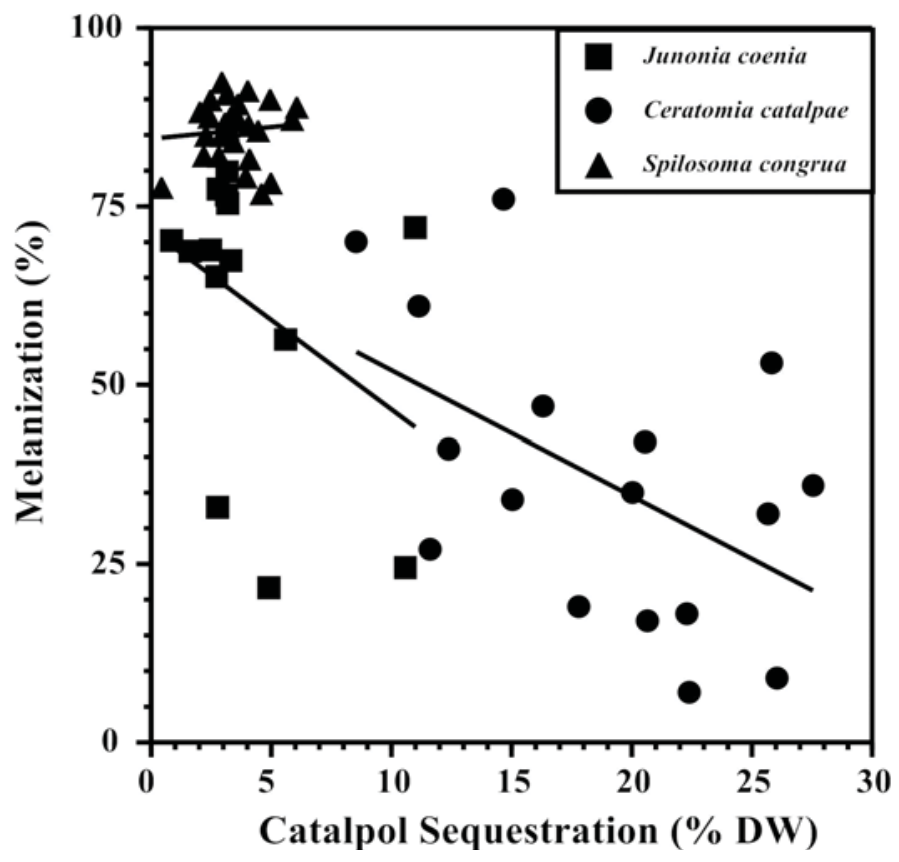

Biological control by pathogens (including nematodes, viruses, bacteria, and fungi) and endoparasitoids and breeding/transgenic plants that express anti-herbivore traits are both important components of integrated pest management programs [17]. Plant traits such as defensive compounds that are detrimental to natural enemies lead to a potential incompatibility between these pest management strategies, and detrimental effects on natural enemies have been shown in several studies (reviewed in $[76,78,126])$. Careful examination of immune response can elucidate whether detrimental interactions between biocontrol agents and pest-resistant plants are direct or indirect, and potentially make these strategies more compatible. Plant traits have been linked to immune response in important field and greenhouse pests, such as the specialist Manduca sexta [127], and the generalist Trichoplusia ni [66], although not in agroecosystems. Potential candidates for further study include generalist Lepidoptera (e.g., Heliothis virescens, Helicoverpa zea, and Spodoptera spp., all Noctuidae), Orthoptera, and Hemiptera (e.g., Aphididae) which attack several crop species that are well-studied in plant-herbivore interaction ecological research.

\section{Conclusions}

Host plant traits are important biotic factors with strong influences on the ecology and evolution of herbivores, and their specialist natural enemies such as pathogens and endoparasitoids. Generalist and specialist herbivores can respond very differently to host plant defensive and nutritive traits, and these 
varied responses may be apparent in higher trophic level interactions as well. A detailed understanding of the effect of plant traits on herbivore immune responses provides a mechanistic explanation for the oft-observed tritrophic interactions among plant, herbivores, and endoparasitic natural enemies, and can produce important insights into the role of biotic and abiotic influences on disease susceptibility and transmission.

\section{Acknowledgments}

Carolina Quintero, Mary Jamieson, and two anonymous reviewers have provided insightful comments on an earlier draft of this manuscript.

\section{References}

1. Martin, L.B.; Hawley, D.M.; Ardia, D.R. An introduction to ecological immunology. Funct. Ecol. 2011, 25, 1-4.

2. Schulenburg, H.; Kurtz, J.; Moret, Y.; Siva-Jothy, M.T. Ecological immunology. Philos. Trans. R. Soc. B-Biol. Sci. 2009, 364, 3-14.

3. Sheldon, B.C.; Verhulst, S. Ecological immunology: Costly parasite defences and trade-offs in evolutionary ecology. Trends Ecol. Evol. 1996, 11, 317-321.

4. Siva-Jothy, M.T.; Thompson, J.J.W. Short-term nutrient deprivation affects immune function. Physiol. Entomol. 2002, 27, 206-212.

5. Siva-Jothy, M.T.; Tsubaki, Y.; Hooper, R.E. Decreased immune response as a proximate cost of copulation and oviposition in a damselfly. Physiol. Entomol. 1998, 23, 274-277.

6. Rolff, J.; Siva-Jothy, M.T. Invertebrate ecological immunology. Science 2003, 301, 472-475.

7. Gillespie, J.P.; Kanost, M.R.; Trenczek, T. Biological mediators of insect immunity. Annu. Rev. Entomol. 1997, 42, 611-643.

8. Strand, M.R. The insect cellular immune response. Insect Sci. 2008, 15, 1-14.

9. Hughes, T.T.; Allen, A.L.; Bardin, J.E.; Christian, M.N.; Daimon, K.; Dozier, K.D.; Hansen, C.L.; Holcomb, L.M.; Ahlander, J. Drosophila as a genetic model for studying pathogenic human viruses. Virology 2012, 423, 1-5.

10. Chamilos, G.; Samonis, G.; Kontoyiannis, D.P. Drosophila melanogaster as a model host for the study of microbial pathogenicity and the discovery of novel antimicrobial compounds. Curr. Pharm. Design 2011, 17, 1246-1253.

11. Tang, H.P. Regulation and function of the melanization reaction in Drosophila. Fly 2009, 3, $105-111$.

12. Gonzalez-Santoyo, I.; Cordoba-Aguilar, A. Phenoloxidase: A key component of the insect immune system. Entomol. Exp. Appl. 2012, 142, 1-16.

13. Belden, L.K.; Harris, R.N. Infectious diseases in wildlife: The community ecology context. Front. Ecol. Environ. 2007, 5, 533-539.

14. Torchin, M.E.; Mitchell, C.E. Parasites, pathogens, and invasions by plants and animals. Front. Ecol. Environ. 2004, 2, 183-190.

15. McCallum, H.; Dobson, A. Detecting disease and parasite threats to endangered species and ecosystems. Trends Ecol. Evol. 1995, 10, 190-194. 
16. Rodriguez, M.A.; Hawkins, B.A. Diversity, function and stability in parasitoid communities. Ecol. Lett. 2000, 3, 35-40.

17. Pedigo, L.; Rice, M. Entomology and Pest Management, 6th ed.; Prentice Hall: Upper Saddle River, NJ, USA, 2009.

18. Hajek, A.E.; Delalibera, I. Fungal pathogens as classical biological control agents against arthropods. Biocontrol 2010, 55, 147-158.

19. Hajek, A.E.; McManus, M.L.; Delalibera, I. A review of introductions of pathogens and nematodes for classical biological control of insects and mites. Biol. Control 2007, 41, 1-13.

20. Schoonhoven, L.; van Loon, J.J.A.; Dicke, M. Insect-Plant Biology; Oxford University Press: New York, NY, USA, 2005.

21. Mechaber, W.L.; Hildebrand, J.G. Novel, non-solanaceous hostplant record for Manduca sexta (Lepidoptera : Sphingidae) in the southwestern United States. Ann. Entomol. Soc. Am. 2000, 93, 447-451.

22. Fox, L.R.; Morrow, P.A. Specialization-Species property or local phenomenon. Science 1981, 211, 887-893.

23. Bernays, E.A.; Minkenberg, O. Insect herbivores: Different reasons for being a generalist. Ecology 1997, 78, 1157-1169.

24. Bernays, E.A.; Singer, M. Contrasted foraging tactics in two species of polyphagous caterpillars. Acta Zool. Acad. Sci. Hung. 2002, 48, 117-135.

25. Berenbaum, M.R.; Feeny, P. Chemical Mediation of Hostplant Specialization-the Papilio Paradigm. In Specialization, Speciation, and Radiation: The evolutionary Biology of Herbivorous Insects; Tilmon, K., Ed.; University of California Press: Berkeley, CA, USA, 2008; pp. 3-19.

26. Strong, D.R. Insect host range. Ecology 1988, 69, 885-885.

27. Ehrlich, P.R.; Raven, P.H. Butterflies and plants - a study in coevolution. Evolution 1964, 18, 586-608.

28. Hairston, N.G.; Smith, F.E.; Slobodkin, L.B. Community structure, population control, and competition. Am. Nat. 1960, 94, 421-425.

29. Thompson, J.N. Coevolution and alternative hypotheses on insect plant interactions. Ecology 1988, 69, 893-895.

30. Tosh, C.R.; Powell, G.; Hardie, J. Decision making by generalist and specialist aphids with the same genotype. J. Insect Physiol. 2003, 49, 659-669.

31. Bowers, M.D.; Puttick, G.M. Response of generalist and specialist insects to qualitative allelochemical variation. J. Chem. Ecol. 1988, 14, 319-334.

32. Johnson, K.S. Comparative detoxification of plant (Magnolia virginiana) allelochemicals by generalist and specialist saturniid silkmoths. J. Chem. Ecol. 1999, 25, 253-269.

33. Richards, L.A.; Dyer, L.A.; Smilanich, A.M.; Dodson, C.D. Synergistic effects of amides from two Piper species on generalist and specialist herbivores. J. Chem. Ecol. 2010, 36, 1105-1113.

34. Ballhorn, D.J.; Kautz, S.; Lieberei, R. Comparing responses of generalist and specialist herbivores to various cyanogenic plant features. Entomol. Exp. Appl. 2010, 134, 245-259.

35. Hagele, B.F.; Rowell-Rahier, M. Choice, performance and heritability of performance of specialist and generalist insect herbivores towards cacalol and seneciphylline, two allelochemicals of Adenostyles alpina (Asteraceae). J. Evol. Biol. 2000, 13, 131-142. 
36. Olivares-Donoso, R.; Troncoso, A.J.; Tapia, D.H.; Aguilera-Olivares, D.; Niemeyer, H.M. Contrasting performances of generalist and specialist Myzus persicae (Hemiptera : Aphididae) reveal differential prevalence of maternal effects after host transfer. Bull. Entomol. Res. 2007, 97, $61-67$.

37. Agrawal, A.A.; Gorski, P.M.; Tallamy, D.W. Polymorphism in plant defense against herbivory: Constitutive and induced resistance in Cucumis sativus. J. Chem. Ecol. 1999, 25, 2285-2304.

38. Reudler, J.H.; Biere, A.; Harvey, J.A.; van Nouhuys, S. Differential performance of a specialist and two generalist herbivores and their parasitoids on Plantago lanceolata. J. Chem. Ecol. 2011, 37, 765-778.

39. Lampert, E.C.; Zangerl, A.R.; Berenbaum, M.R.; Ode, P.J. Generalist and specialist hostparasitoid associations respond differently to wild parsnip (Pastinaca sativa) defensive chemistry. Ecol. Entomol. 2011, 36, 52-61.

40. Sznajder, B.; Harvey, J.A. Second and third trophic level effects of differences in plant species reflect dietary specialisation of herbivores and their endoparasitoids. Entomol. Exp. Appl. 2003, $109,73-82$.

41. Harvey, J.A.; Van Nouhuys, S.; Biere, A. Effects of quantitative variation in allelochemicals in Plantago lanceolata on development of a generalist and a specialist herbivore and their endoparasitoids. J. Chem. Ecol. 2005, 31, 287-302.

42. Bernays, E.; Graham, M. On the evolution of host specificity in phytophagous arthropods. Ecology 1988, 69, 886-892.

43. Dyer, L.A. Tasty generalists and nasty specialists - Antipredator mechanisms in tropical lepidopteran larvae. Ecology 1995, 76, 1483-1496.

44. Hawkins, B.A.; Cornell, H.V.; Hochberg, M.E. Predators, parasitoids, and pathogens as mortality agents in phytophagous insect populations. Ecology 1997, 78, 2145-2152.

45. Singer, M.S.; Stireman, J.O. Does anti-parasitoid defense explain host-plant selection by a polyphagous caterpillar? Oikos 2003, 100, 554-562.

46. Singer, M.S.; Stireman, J.O. The tri-trophic niche concept and adaptive radiation of phytophagous insects. Ecol. Lett. 2005, 8, 1247-1255.

47. Smilanich, A.M.; Mason, P.A.; Sprung, L.; Chase, T.R.; Singer, M.S. Complex effects of parasitoids on pharmacophagy and diet choice of a polyphagous caterpillar. Oecologia 2011, $165,995-1005$.

48. Singer, M.S.; Mace, K.C.; Bernays, E.A. Self-medication as adaptive plasticity: Increased ingestion of plant toxins by parasitized caterpillars. PLoS One 2009, doi:10.1371/journal.pone.0004796.

49. Lill, J.T.; Marquis, R.J.; Ricklefs, R.E. Host plants influence parasitism of forest caterpillars. Nature 2002, 417, 170-173.

50. Feder, J.L. The effects of parasitoids on sympatric host races of Rhagoletis-pomonella (Diptera, Tephritidae). Ecology 1995, 76, 801-813.

51. Mira, A.; Bernays, E.A. Trade-offs in host use by Manduca sexta: Plant characters vs natural enemies. Oikos 2002, 97, 387-397.

52. Dunn, P.E. Humoral immunity in insects. Bioscience 1990, 40, 738-744. 
53. Gillespie, J.P.; Bailey, A.M.; Cobb, B.; Vilcinskas, A. Fungi as elicitors of insect immune responses. Arch. Insect Biochem. Physiol. 2000, 44, 49-68.

54. Lavine, M.D.; Strand, M.R. Insect hemocytes and their role in immunity. Insect Biochem. Mol. Biol. 2002, 32, 1295-1309.

55. Carton, Y.; Poirie, M.; Nappi, A.J. Insect immune resistance to parasitoids. Insect Sci. 2008, 15, 67-87.

56. Vogelweith, F.; Thiery, D.; Quaglietti, B.; Moret, Y.; Moreau, J. Host plant variation plastically impacts different traits of the immune system of a phytophagous insect. Funct. Ecol. 2011, 25, $1241-1247$.

57. Myers, J.H.; Cory, J.S.; Ericsson, J.D.; Tseng, M.L. The effect of food limitation on immunity factors and disease resistance in the western tent caterpillar. Oecologia 2011, 167, 647-655.

58. Smilanich, A.M.; Dyer, L.A.; Gentry, G.L. The insect immune response and other putative defenses as effective predictors of parasitism. Ecology 2009, 90, 1434-1440.

59. Siva-Jothy, M.T.; Moret, Y.; Rolff, J., Insect Immunity: An Evolutionary Ecology Perspective. In Advances in Insect Physiology, vol 32, Elsevier Academic Press Inc: San Diego, CA, USA, 2005; Volume 32, pp. 1-48.

60. Klemola, T.; Klemola, N.; Andersson, T.; Ruohomaki, K. Does immune function influence population fluctuations and level of parasitism in the cyclic geometrid moth? Popul. Ecol. 2007, $49,165-178$.

61. Klemola, N.; Kapari, L.; Klemola, T. Host plant quality and defence against parasitoids: No relationship between levels of parasitism and a geometrid defoliator immunoassay. Oikos 2008, 117, 926-934.

62. Nappi, A.J.; Christensen, B.M. Melanogenesis and associated cytotoxic reactions: Applications to insect innate immunity. Insect Biochem. Mol. Biol. 2005, 35, 443-459.

63. Marmaras, V.J.; Charalambidis, N.D.; Zervas, C.G. Immune response in insects: The role of phenoloxidase in defense reactions in relation to melanization and sclerotization. Arch. Insect Biochem. Physiol. 1996, 31, 119-133.

64. Cornet, S.; Biard, C.; Moret, Y. Variation in immune defence among populations of Gammarus pulex (Crustacea: Amphipoda). Oecologia 2009, 159, 257-269.

65. Klemola, N.; Klemola, T.; Rantala, M.J.; Ruuhola, T. Natural host-plant quality affects immune defence of an insect herbivore. Entomol. Exp. Appl. 2007, 123, 167-176.

66. Shikano, I.; Ericsson, J.D.; Cory, J.S.; Myers, J.H. Indirect plant-mediated effects on insect immunity and disease resistance in a tritrophic system. Basic Appl. Ecol. 2010, 11, 15-22.

67. Godfray, H.C.J. Parasitoids: Behavioral and Evolutionary Ecology; Princeton University Press: Princeton, NJ, USA, 1994.

68. Quicke, D. Parasitic Wasps; Chapman \& Hall: London, UK, 1997.

69. Mayhew, P.J. The evolution of gregariousness in parasitoid wasps. Proc. R. Soc. Lond. Ser. B-Biol. Sci. 1998, 265, 383-389.

70. Kapari, L.; Haukioja, E.; Rantala, M.J.; Ruuhola, T. Defoliating insect immune defense interacts with induced plant defense during a population outbreak. Ecology 2006, 87, 291-296.

71. Lavine, M.D.; Beckage, N.E. Temporal pattern of parasitism-induced immunosuppression in Manduca sexta larvae parasitized by Cotesia congregata. J. Insect Physiol. 1996, 42, 41-51. 
72. Lu, J.F.; Hu, J.; Fu, W.J. Levels of encapsulation and melanization in two larval instars of Ostrinia furnacalis Guenee (Lep. Pyralidae) during simulation of parasitization by Macrocentrus cingulum Brischke (Hym. Braconidae). J. Appl. Entomol. 2006, 130, 290-296.

73. Smilanich, A.M.; Vargas, J.; Dyer, L.A.; Bowers, M.D. Effects of ingested secondary metabolites on the immune response of a polyphagous caterpillar Grammia incorrupta. J. Chem. Ecol. 2011, 37, 239-245.

74. Whittaker, H.; Feeny, P.P. Allelochemics-Chemical interactions between species. Science 1971, 171, 757-770.

75. Lampert, E.C. Gainesville State College, Oakwood, GA, USA. Unpublished work. 2012.

76. Hare, J.D.; Luck, R.F. Plant Genetic Variation in Tritrophic Interactions. In Multitrophic Level Interactions, 2nd ed.; Tscharntke, T.H.B., Ed.; Cambridge University Press: Cambridge, UK, 2002.

77. Cory, J.S.; Hoover, K. Plant-mediated effects in insect-pathogen interactions. Trends Ecol. Evol. 2006, 21, 278-286.

78. Ode, P.J. Plant chemistry and natural enemy fitness: Effects on herbivore and natural enemy interactions. Annu. Rev. Entomol. 2006, 51, 163-185.

79. Bernays, E.A.; Singer, M.S.; Rodrigues, D. Foraging in nature: Foraging efficiency and attentiveness in caterpillars with different diet breadths. Ecol. Entomol. 2004, 29, 389-397.

80. Chambers, P.; Sword, G.; Angel, J.E.; Behmer, S.; Bernays, E.A. Foraging by generalist grasshoppers: Two different strategies. Anim. Behav. 1996, 52, 155-165.

81. Howard, J.J.; Raubenheimer, D.; Bernays, E.A. Population and individual polyphagy in the grasshopper Taeniopoda eques during natural foraging. Entomol. Exp. Appl. 1994, 71, 167-176.

82. Miura, K.; Ohsaki, N. Diet mixing and its effect on polyphagous grasshopper nymphs. Ecol. Res. 2004, 19, 269-274.

83. Bernays, E.A.; Bright, K.L.; Gonzalez, N.; Angel, J. Dietary mixing in a generalist herbivoreTests of 2 hypotheses. Ecology 1994, 75, 1997-2006.

84. Ojala, K.; Julkunen-Tiito, R.; Lindstrom, L.; Mappes, J. Diet affects the immune defence and life-history traits of an arctiid moth Parasemia plantaginis. Evol. Ecol. Res. 2005, 7, 1153-1170.

85. Ruohomaki, K.; Tanhuanpaa, M.; Ayres, M.P.; Kaitaniemi, P.; Tammaru, T.; Haukioja, E. Causes of cyclicity of Epirrita autumnata (Lepidoptera, Geometridae): Grandiose theory and tedious practice. Popul. Ecol. 2000, 42, 211-223.

86. Haviola, S.; Kapari, L.; Ossipov, V.; Rantala, M.J.; Ruuhola, T.; Haukioja, E. Foliar phenolics are differently associated with Epirrita autumnata growth and immunocompetence. J. Chem. Ecol. 2007, 33, 1013-1023.

87. Yang, S.Y.; Ruuhola, T.; Haviola, S.; Rantala, M.J. Effects of host-plant shift on immune and other key life-history traits of an eruptive geometrid, Epirrita autumnata (Borkhausen). Ecol. Entomol. 2008, 33, 510-516.

88. Schmid-Hempel, P. Variation in immune defence as a question of evolutionary ecology. Proc. $R$. Soc. Lond. Ser. B-Biol. Sci. 2003, 270, 357-366.

89. Schmid-Hempel, P. Evolutionary ecology of insect immune defenses. Annu. Rev. Entomol. 2005, 50, 529-551. 
90. Smilanich, A.M.; Dyer, L.A.; Chambers, J.Q.; Bowers, M.D. Immunological cost of chemical defence and the evolution of herbivore diet breadth. Ecol. Lett. 2009, 12, 612-621.

91. Diamond, S.E.; Kingsolver, J.G. Host plant quality, selection history and trade-offs shape the immune responses of Manduca sexta. Proc. R. Soc. B-Biol. Sci. 2011, 278, 289-297.

92. Sandre, S.L.; Tammaru, T.; Hokkanen, H.M.T. Pathogen resistance in the moth Orgyia antiqua: Direct influence of host plant dominates over the effects of individual condition. Bull. Entomol. Res. 2011, 101, 107-114.

93. Bukovinszky, T.; Poelman, E.H.; Gols, R.; Prekatsakis, G.; Vet, L.E.M.; Harvey, J.A.; Dicke, M. Consequences of constitutive and induced variation in plant nutritional quality for immune defence of a herbivore against parasitism. Oecologia 2009, 160, 299-308.

94. Karimzadeh, J.; Wright, D.J. Bottom-up cascading effects in a tritrophic system: Interactions between plant quality and host-parasitoid immune responses. Ecol. Entomol. 2008, 33, 45-52.

95. Lee, K.P.; Simpson, S.J.; Wilson, K. Dietary protein-quality influences melanization and immune function in an insect. Funct. Ecol. 2008, 22, 1052-1061.

96. Awmack, C.S.; Leather, S.R. Host plant quality and fecundity in herbivorous insects. Annu. Rev. Entomol. 2002, 47, 817-844.

97. Nappi, A.J.; Vass, E.; Frey, F.; Carton, Y. Superoxide anion generation in Drosophila during melanotic encapsulation of parasites. Eur. J. Cell Biol. 1995, 68, 450-456.

98. von Schantz, T.; Bensch, S.; Grahn, M.; Hasselquist, D.; Wittzell, H. Good genes, oxidative stress and condition-dependent sexual signals. Proc. R. Soc. Lond. Ser. B-Biol. Sci. 1999, 266, $1-12$.

99. Sadd, B.M.; Siva-Jothy, M.T. Self-harm caused by an insect's innate immunity. Proc. R. Soc. B-Biol. Sci. 2006, 273, 2571-2574.

100. Johnson, K.S.; Felton, G.W. Plant phenolics as dietary antioxidants for herbivorous insects: A test with genetically modified tobacco. J. Chem. Ecol. 2001, 27, 2579-2597.

101. Babin, A.; Biard, C.; Moret, Y. Dietary supplementation with carotenoids improves immunity without increasing its cost in a crustacean. Am. Nat. 2010, 176, 234-241.

102. Schütz, K.; Carle, R.; Schieber, A. Taraxacum-A review on its phytochemical and pharmacological profile. J. Ethnopharmacol. 2006, 107, 313-323.

103. Afolayan, A.J.; Aboyade, O.M.; Sofidiya, M.O. Total phenolic content and free radical scavenging activity of Malva parviflora L. (Malvaceae). J. Biol. Sci. 2008, 8, 945-949.

104. Li, X.C.; Baudry, J.; Berenbaum, M.R.; Schuler, M.A. Structural and functional divergence of insect CYP6b proteins: From specialist to generalist cytochrome p450. Proc. Natl. Acad. Sci. USA 2004, 101, 2939-2944.

105. Krieger, R.I.; Feeny, P.P.; Wilkinso, C.f. Detoxication enzymes in guts of caterpillars evolutionary answer to plant defenses. Science 1971, 172, 579-581.

106. Niu, G.D.; Rupasinghe, S.G.; Zangerl, A.R.; Siegel, J.P.; Schuler, M.A.; Berenbaum, M.R. A substrate-specific cytochrome p450 monooxygenase, CYP6ab11, from the polyphagous navel orangeworm (Amyelois transitella). Insect Biochem. Mol. Biol. 2011, 41, 244-253.

107. Hopkins, R.J.; van Dam, N.M.; van Loon, J.J.A. Role of glucosinolates in insect-plant relationships and multitrophic interactions. Annu. Rev. Entomol. 2009, 54, 57-83. 
108. Camara, M.D. Physiological mechanisms underlying the costs of chemical defence in Junonia coenia Hübner (Nymphalidae): A gravimetric and quantitative genetic analysis. Evol. Ecol. 1997, 11, 451-469.

109. Laurentz, M.; Reudler, J.H.; Mappes, J.; Friman, V.; Ikonen, S.; Lindstedt, C. Diet quality can play a critical role in defense efficacy against parasitoids and pathogens in the glanville fritillary (Melitaea cinxia). J. Chem. Ecol. 2012, 38, 116-125.

110. Nishida, R. Sequestration of defensive substances from plants by Lepidoptera. Annu. Rev. Entomol. 2002, 47, 57-92.

111. Opitz, S.E.W.; Muller, C. Plant chemistry and insect sequestration. Chemoecology 2009, 19, $117-154$.

112. Lampert, E.C.; Bowers, M.D. Host plant influences on iridoid glycoside sequestration of generalist and specialist caterpillars. J. Chem. Ecol. 2010, 36, 1101-1104.

113. Gentry, G.L.; Dyer, L.A. On the conditional, nature of neotropical caterpillar defenses against their natural enemies. Ecology 2002, 83, 3108-3119.

114. Lampert, E.C.; Dyer, L.A.; Bowers, M.D. Caterpillar chemical defense and parasitoid success: Cotesia congregata parasitism of Ceratomia catalpae. J. Chem. Ecol. 2010, 36, 992-998.

115. Le Guigo, P.; Qu, Y.; Le Corff, J. Plant-mediated effects on a toxin-sequestering aphid and its endoparasitoid. Basic Appl. Ecol. 2011, 12, 72-79.

116. Hartmann, T.; Theuring, C.; Beuerle, T.; Bernays, E.A.; Singer, M.S. Acquisition, transformation and maintenance of plant pyrrolizidine alkaloids by the polyphagous arctiid Grammia geneura. Insect Biochem. Mol. Biol. 2005, 35, 1083-1099.

117. Narberhaus, I.; Papke, U.; Theuring, C.; Beuerle, T.; Hartmann, T.; Dobler, S. Direct evidence for membrane transport of host-plant-derived pyrrolizidine alkaloid n-oxides in two leaf beetle genera. J. Chem. Ecol. 2004, 30, 2003-2022.

118. Bowers, M.D. The Evolution of Unpalatability and the Cost of Chemical Defense in Insects. In Insect Chemical Ecology: An Evolutionary Approach; Roitberg, B.D., Isman, M.B., Eds.; Chapman \& Hall: New York, NY, USA, 1992.

119. Dobler, S.; Petschenka, G.; Pankoke, H. Coping with toxic plant compounds - The insect's perspective on iridoid glycosides and cardenolides. Phytochemistry 2011, 72, 1593-1604.

120. Dyer, L.A.; Bowers, M.D. The importance of sequestered iridoid glycosides as a defense against an ant predator. J. Chem. Ecol. 1996, 22, 1527-1539.

121. Camara, M.D. Predator responses to sequestered plant toxins in buckeye caterpillars: Are tritrophic interactions locally variable? J. Chem. Ecol. 1997, 23, 2093-2106.

122. Alaux, C.; Ducloz, F.; Crauser, D.; Le Conte, Y. Diet effects on honeybee immunocompetence. Biol. Lett. 2010, 6, 562-565.

123. Anagnostou, C.; LeGrand, E.A.; Rohlfs, M. Friendly food for fitter flies?-Influence of dietary microbial species on food choice and parasitoid resistance in Drosophila. Oikos 2010, 119, 533-541.

124. Conner, W.E. Utetheisa ornatrix, the Ornate Arctiid. In Tiger Moths and Woolly Bears: Behavior, Ecology, and Evolution of the Arctiidae; Conner, W., Ed.; Oxford University Press: New York, NY, USA, 2009. 
125. Berenbaum, M.R. Evolution of specialization in insect-umbellifer associations. Annu. Rev. Entomol. 1990, 35, 319-343.

126. Gatehouse, A.M.R.; Ferry, N.; Edwards, M.G.; Bell, H.A. Insect-resistant biotech crops and their impacts on beneficial arthropods. Philos. Trans. R. Soc. B-Biol. Sci. 2011, 366, 1438-1452.

127. Diamond, S.E.; Kingsolver, J.G. Fitness consequences of host plant choice: A field experiment. Oikos 119, 542-550.

(C) 2012 by the author; licensee MDPI, Basel, Switzerland. This article is an open access article distributed under the terms and conditions of the Creative Commons Attribution license (http://creativecommons.org/licenses/by/3.0/). 